\title{
KERAGAMAN FENOTIPE TRUSS MORFOMETRIK DAN GENOTIPE IKAN GABUS (Channa striata) DARI JAWA BARAT, SUMATERA SELATAN, DAN KALIMANTAN TENGAH
}

\author{
Irin Iriana Kusmini" ${ }^{2}$, Vitas Atmadi Prakoso", dan Kusdiarti") \\ ") Balai Penelitian dan Pengembangan Budidaya Air Tawar \\ 7) Pusat Penelitian dan Pengembangan Perikanan Budidaya
}

(Naskah diterima: 29 September 2015; Revisi final: 7 November 2015; Disetujui publikasi: 9 November 2015)

\begin{abstract}
ABSTRAK
Ikan gabus di Indonesia awalnya hanya terdapat di Barat garis Wallace (Sumatera, Jawa, dan Kalimantan) yang kemudian diintroduksi ke Indonesia bagian Timur. Ikan gabus termasuk ke dalam deretan ikan air tawar sebagai sumber daya genetik untuk menunjang diversifikasi usaha budidaya. Guna menyukseskan program diversifikasi tersebut, maka perlu diketahui keragaman genetik ikan gabus dari Jawa Barat, Sumatera Selatan, dan Kalimantan Tengah agar dapat direkomendasikan sebagai dasar pemuliaan. Tujuan penelitian ini untuk menganalisis keragaman dan kekerabatan antara populasi ikan gabus dari Jawa Barat, Sumatera Selatan, dan Kalimantan tengah. Metode penelitian dilakukan dengan analisis fenotipe terhadap 16 ekor ikan sampel dari masing-masing daerah tersebut, sedangkan untuk analisis keragaman genotipe masingmasing digunakan 10 ekor ikan dari setiap daerah. Analisis tersebut dilakukan melalui truss morfometrik dan RAPD dengan primer OPA-10, OPA-11, dan OPA-15. Hasil penelitian menunjukkan keragaman berdasarkan truss morfometrik dan hasil PCR ikan gabus asal Sumatera Selatan lebih tinggi dibandingkan Kalimantan Tengah dan Jawa Barat. Kekerabatan ikan gabus Kalimantan Tengah lebih dekat dengan ikan gabus Sumatera Selatan dibandingkan dengan ikan gabus Jawa Barat. Hasil penelitian ini dapat dijadikan sebagai informasi untuk pertimbangan dalam program pemuliaan.
\end{abstract}

KATA KUNCI: $\quad$ ikan gabus, Channa striata, RAPD, truss morfometrik, genotipe, populasi

ABSTRACT: Phenotype truss morphometric and genotype variation of snakehead (Channa striata) from West Java, South Sumatra, and Central Kalimantan. By: Irin Iriana Kusmini, Vitas Atmadi Prakoso, and Kusdiarti

Snakehead in Indonesia was originally found in the West of Wallace line (Sumatra, Java, and Borneo). Then, it was introduced to the eastern part of Indonesia. Snakehead was one of the freshwater fish included as genetic resources to support the diversification of farmed fish species. In order to succeed the program of diversification, it was necessary to determine the genetic variety of snakehead from West Java, South Sumatra, and Central of Kalimantan population in order to make recommendation for the basis of selective breeding. The aim of this study was to analyze the diversity and genetic relationship between snakehead populations from West Java, South Sumatra, and Central Kalimantan. Analysis of phenotype from the sixteen fish samples in each population was investigated. Furthermore, genotype variability was analyzed from ten samples of fish in each population. The analysis was conducted through truss morphometric and RAPD with OPA-10, OPA-11, and OPA-15 primers. Results showed that variety in truss morphometric and genotype of snakehead from South Sumatra was higher than Central Kalimantan and West Java. Genetic relationship showed that snakehead from Central Kalimantan population was closer or more similar to South Sumatra population than West Java. The results of this study could be used as information to be considered in breeding programs.

KEYWORDS: $\quad$ snakehead, Channa striata, RAPD, truss morphometric, genotype, population

\# Korespondensi: Balai Penelitian dan Pengembangan

Perikanan Budidaya Air Tawar. Jl. Raya Sempur No. 1, Bogor

16154, Indonesia. Tel.: + (0251) 8313200

E-mail: iriniriana@gmail.com 


\section{PENDAHULUAN}

Di antara komoditas air tawar yang memiliki nilai ekonomis tinggi, ikan gabus (Channa striata) merupakan jenis asli Kalimantan dan Sumatera yang merupakan salah satu komoditas dalam komposisi 22 jenis ikan air tawar sebagai sumber daya genetik untuk kegiatan budidaya dalam menunjang diversifikasi usaha budidaya (Gustiano, 2007). Shafri \& Manan (2012) mengatakan bahwa dalam dunia kesehatan daging ikan gabus dapat digunakan untuk membantu mempercepat proses penyembuhan luka, ketahanan tubuh, antinyeri, antijamur, dan antibakteri. Ikan gabus dari Kalimantan dan Sumatera banyak dikonsumsi sebagai bahan makanan khas daerah, selain itu, juga untuk memenuhi permintaan industri obat karena kandungan albuminnya. Daging ikan gabus mengandung protein hingga $70 \%$ dan albumin hingga 21\% (Kordi, 2010).

Keberadaan ikan gabus di alam sudah mulai berkurang. Selain karena eksploitasi yang berlebihan, ekosistem dari habitat ikan ini juga telah rusak akibat dari pestisida, limbah pabrik, dan cuaca ekstrim. Populasi dengan keragaman genetik yang tinggi memiliki peluang hidup yang lebih tinggi, karena banyak alternatif gen atau kombinasi gen yang tersedia untuk merespons perubahan kondisi lingkungan yang dihadapi (Dunham, 2004). Menurut Tave (1986), koefisien keragaman fenotipe dipengaruhi oleh faktor genetik, lingkungan, dan interaksi genetis dengan lingkungan. Untuk pengembangan budidaya dan pengelolaan sumber daya genetik ikan gabus, maka informasi keragaman populasi ikan gabus berdasarkan lokasi geografis perlu dilakukan.

Tujuan dari penelitian ini yaitu untuk mengevaluasi keragaman dan kekerabatan antara populasi ikan gabus dari Jawa Barat, Sumatera Selatan, dan Kalimantan Tengah. Informasi tersebut dapat menjadi pertimbangan dalam pemuliaan.

\section{BAHAN DAN METODE}

\section{Sampel}

Sampel ikan gabus yang digunakan berasal dari Kalimantan Tengah (Kuala Kapuas), Sumatera Selatan (Palembang), dan Jawa Barat (Parung). Jumlah sampel yang digunakan untuk analisis RAPD adalah 10 ekor untuk tiap sumber, sedangkan untuk analisis truss morfometrik ikan gabus yang digunakan yaitu sebanyak 16 ekor dari masing-masing daerah.

\section{Karakterisasi Genotipe dengan RAPD}

\section{Ekstraksi DNA}

Proses ekstraksi DNA menggunakaan metode phenol-chloroform (Nugroho et al., 1997), dimulai dengan diambilnya sirip dari setiap sampel ikan sebanyak 5$10 \mathrm{mg}$, selanjutnya dimasukkan ke dalam tabung yang telah berisi $500 \mu \mathrm{L}$ larutan TNES urea. Kemudian sample ditambahkan 15 proteinase lalu dihomogenasi dengan vortex dan diinkubasi pada suhu $55^{\circ} \mathrm{C}$ selama satu jam. Selanjutnya campuran tersebut dihomogenasi dengan vortex dan ditambahkan larutan phenol:chloroform sebanyak $1.000 \mu \mathrm{L}$. Lalu dilakukan sentrifugasi $10.000 \mathrm{rpm}$ selama 10 menit. Supernatan yang terbentuk dipindahkan ke dalam tabung baru dan ditambahkan etanol 90\% sebanyak $1.000 \mu \mathrm{L}$ dan Naasetat sebanyak $10 \mu \mathrm{L}$. Setelah itu, campuran disentrifugasi dengan kecepatan 10.000 rpm selama 10 menit hingga terbentuk endapan warna putih. Hasil dari campuran tersebut lalu dipisahkan antara DNA dengan larutan, DNA yang telah terpisah dikeringkan dalam suhu kamar. Selanjutnya DNA dilarutkan dengan 50-100 $\mu \mathrm{L}$ tris-EDTA.

\section{Amplifikasi DNA dengan Teknik PCR}

Amplifikasi DNA dilakukan menggunakan metode PCR dimulai dengan seleksi 25 primer. Pengujian primer dari OPA-01 sampai OPA-20 dan OPC-01 sampai OPC-05 dengan komposisi bahan $1 \mu \mathrm{L}$ DNA template konsentrasi $10 \mu \mathrm{g}$; $0,5 \mu \mathrm{L}$ primer konsentrasi $10 \mathrm{pmol}$; $8,5 \mu \mathrm{L}$ akuades, dan $10 \mu \mathrm{L}$ Taq polymerase dengan volume total sebanyak $20 \mu \mathrm{L}$. Setelah itu, larutan dihomogenkan dengan vortex, di-spindown kemudian dimasukkan ke dalam mesin PCR. Program PCR yang digunakan, yaitu pre-denaturasi pada $94^{\circ} \mathrm{C}$ selama lima menit, denaturasi pada suhu $94^{\circ} \mathrm{C}$ selama 40 detik, annealing pada suhu $35^{\circ} \mathrm{C}$ selama satu menit, elongasi pada suhu $72^{\circ} \mathrm{C}$ selama dua menit, elongasi akhir pada suhu $72^{\circ} \mathrm{C}$ selama tujuh menit, dan proses penstabilan pada suhu $4^{\circ} \mathrm{C}$ selama tiga menit. Proses PCR ini berlangsung sebanyak 40 siklus (Hassanien et al., 2004). Hasil PCR memperlihatkan bahwa primer OPA10, OPA-11, dan OPA-15 memberikan produk amplifikasi lebih banyak dibandingkan primer-primer yang lain. Hasil PCR kemudian dipisahkan secara elektroforesis dengan menggunakan gel agarose $2 \%$ dalam buffer Tris-Boric-EDTA (TBE) dan diamati dengan illuminator (UV), serta dicetak gambarnya dengan polaroid.

\section{Analisis Keragaman Genotipe}

Heterozigositas merupakan perpaduan dari alelalel yang berbeda pada lokus yang sama dihitung berdasarkan persamaan Hardy-Weinberg (Nei, 1978 dalam Miller, 1997). Program Tools for Population Genetic Analysis (TFPGA) digunakan untuk mencari kekerabatan antar perlakuan yang dihitung menurut Wright (1978) modifikasi dari Rogers (1972). 


\section{Karakterisasi Fenotipe Truss Morfometrik}

Ikan gabus pada setiap populasi dipilih 16 ekor secara acak berdasarkan kelengkapan anggota badannya. Selanjutnya dilakukan pemilihan titik-titik truss di tubuh ikan (Gambar 1). Metode pengukuran dilakukan dengan menghubungkan jarak titik-titik spesifik yang bersifat pasti pada tubuh ikan (Strauss \& Fuiman, 1985). Keterangan simbol terdapat pada Tabel 1.

\section{Prosedur Analisis Data Truss Morfometrik}

Data seluruh pengukuran morfometrik dikonversi ke dalam rasio antara setiap pengukuran dibagi dengan panjang standar. Data rasio ukuran dianalisis menggunakan analisis pengelompokan (cluster analysis) untuk mengevaluasi keragaman intrapopulasi dan interpopulasi ikan gabus. Analisis keragaman morfologis antar lokasi dilakukan secara deskriptif

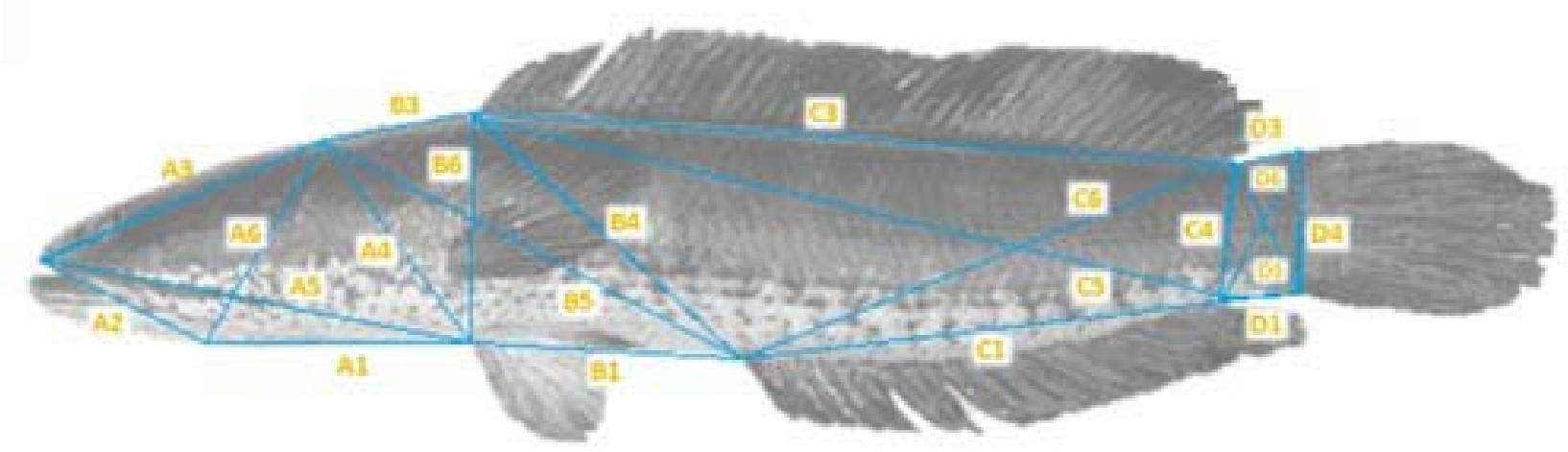

Gambar 1. Pengukuran karakter truss morfometrik

Figure 1. Measurement of truss morphometric characters

Tabel 1. Deskripsi 21 karakter truss morfometrik ikan gabus

Table 1. Description of 21 characters for truss morphometric on snakehead

\begin{tabular}{|c|c|c|}
\hline $\begin{array}{l}\text { Bidang truss } \\
\text { Truss area }\end{array}$ & $\begin{array}{l}\text { Kode } \\
\text { Code }\end{array}$ & $\begin{array}{c}\text { Deskripsi jarak } \\
\text { Description of distance }\end{array}$ \\
\hline \multirow{6}{*}{$\begin{array}{l}\text { Kepala } \\
\text { Head }\end{array}$} & A1 & Ujung bawah operculum - awal sirip perut (Lower end of operculum - beginning of pelvic fins) \\
\hline & A2 & Ujung mulut bagian atas - ujung bawah operculum (Upper end of mouth - the lower end of operculum) \\
\hline & A3 & Ujung mulut bagian atas - bagian akhir tulang kepala (Upper end of mouth - latter part of skull) \\
\hline & A4 & Bagian akhir tulang kepala - awal sirip perut (Latter part of skull - beginning of pelvic fins) \\
\hline & A5 & Ujung mulut bagian atas - awal sirip perut (Upper end of mouth - beginning of pelvic fins) \\
\hline & A6 & Ujung bawah operculum - bagian akhir tulang kepala (Lower end of operculum - latter part of skull) \\
\hline \multirow{5}{*}{$\begin{array}{l}\text { Tengah } \\
\text { badan } \\
\text { Midsection }\end{array}$} & B1 & Awal sirip perut - awal sirip anal (Beginning of pelvic fin - the beginning of the anal fin ) \\
\hline & B3 & Bagian akhir tulang kepala - awal sirip punggung (Latter part of skull - beginning of dorsal fin) \\
\hline & B4 & Awal sirip punggung - awal sirip anal (Beginning of dorsal fin - beginning of anal fin ) \\
\hline & B5 & Bagian akhir tulang kepala - awal sirip anal (Latter part of skull - beginning of anal fin ) \\
\hline & B6 & Awal sirip perut - awal sirip punggung (Beginning of pelvic fin - beginning of dorsal fin ) \\
\hline \multirow{5}{*}{$\begin{array}{l}\text { Badan } \\
\text { belakang } \\
\text { Rear body }\end{array}$} & $\mathrm{C} 1$ & Awal sirip anal - akhir sirip anal (Beginning of anal fin - end of anal fin ) \\
\hline & $\mathrm{C} 3$ & Awal sirip punggung - akhir sirip punggung (Beginning of dorsal fin - end of dorsal fin ) \\
\hline & $\mathrm{C} 4$ & Akhir sirip punggung - akhir sirip anal (End of dorsal fin - end of anal fin ) \\
\hline & $\mathrm{C} 5$ & Awal sirip punggung- akhir sirip anal (Beginning of dorsal fin - end of anal fin ) \\
\hline & C6 & Awal sirip anal - akhir sirip punggung (Beginning of anal fin - end of dorsal fin ) \\
\hline \multirow{5}{*}{$\begin{array}{l}\text { Pangkal } \\
\text { ekor } \\
\text { Caudal } \\
\text { peduncle }\end{array}$} & D1 & Akhir sirip anal - awal sirip ekor bawah (End of anal fin - beginning of lower part of caudal fin) \\
\hline & D3 & Akhir sirip punggung - awal sirip ekor atas (End of dorsal fin - beginning of upper part of caudal fin) \\
\hline & D4 & $\begin{array}{c}\text { Awal sirip ekor atas - awal sirip ekor bawah } \\
\text { Beginning of upper part of caudal fin - beginning of lower part of caudal fin }\end{array}$ \\
\hline & D5 & Akhir sirip punggung - awal sirip ekor bawah (End of dorsal fin - beginning of lower part of caudal fin) \\
\hline & D6 & Akhir sirip anal - awal sirip ekor atas (End of anal fin - beginning of upper part of caudal fin ) \\
\hline
\end{tabular}


dengan membandingkan nilai koefisien keragaman (CV) menurut Singh \& Chaudary (1977).

\section{HASIL DAN BAHASAN}

\section{Keragaman Genotipe}

Keragaman genotipe pada ketiga populasi ikan gabus berdasarkan hasil amplifikasi DNA menggunakan tiga primer, yaitu OPA-10, OPA-11, dan OPA-15 masingmasing ditampilkan pada Gambar 2, 3, dan 4. DNA teramplifikasi dari setiap primer yang digunakan dan bervariasi dalam jumlah situs amplifikasinya.

Populasi ikan gabus Sumatera Selatan memiliki persentase polimorfisme dan heterozigositas yang lebih tinggi dibandingkan populasi lainnya, yaitu 74\% dan 0,2937. Persentase polimorfisme dan heterozigositas ikan gabus Kalimantan Tengah sebesar $40 \%$ dan 0,1573; serta ikan gabus Jawa Barat sebesar $30 \%$ dan 0,1210 (Tabel 2).
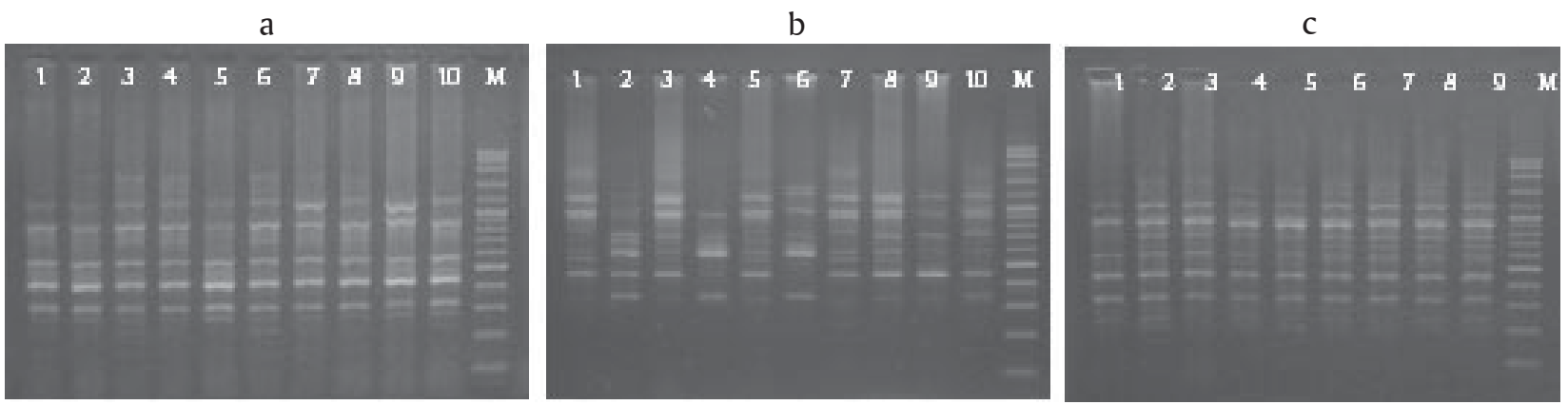

Gambar 2. Hasil amplifikasi DNA ikan gabus Jawa Barat (a), Sumatera Selatan (b), dan Kalimantan Tengah (c) dengan PCR-RAPD menggunakan primer OPA-10 (Keterangan: nomor (1-10) = sampel ikan, $\mathrm{M}=$ marker)

Figure 2. $\quad$ DNA amplification results of snake head from West Java, South Sumatra, and Central Kalimantan by PCRRAPD using OPA-10 primer (Description: number (1-10) = samples, $M=$ marker)
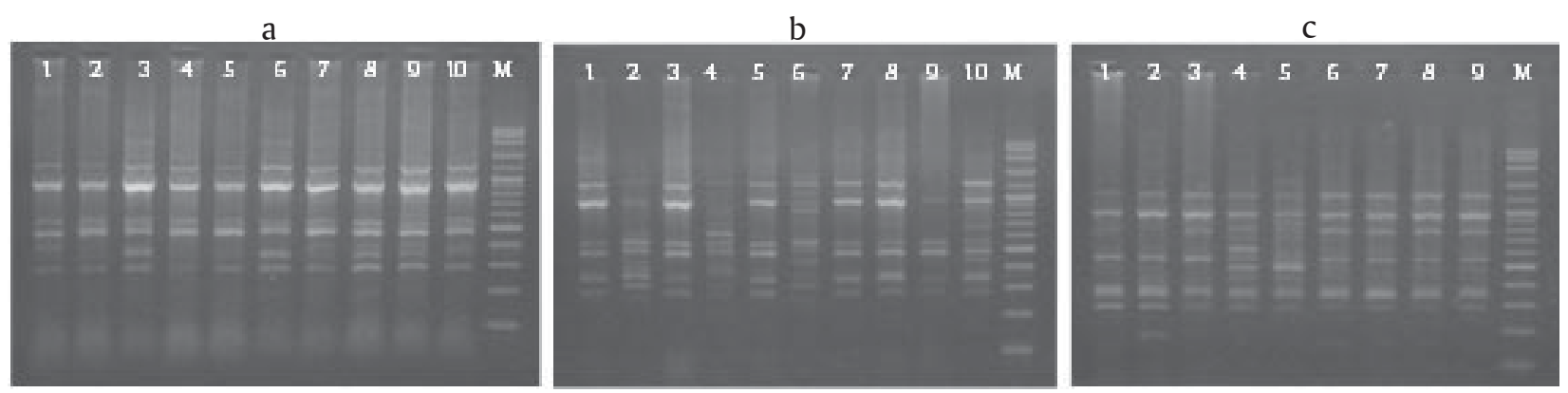

Gambar 3. Hasil amplifikasi DNA ikan gabus Jawa Barat (a), Sumatera Selatan (b), dan Kalimantan Tengah (c) dengan PCR-RAPD menggunakan primer OPA-11 (Keterangan: nomor (1-10) = sampel ikan, $\mathrm{M}=$ marker)

Figure 3. DNA amplification results of snake head from West Java (a), South Sumatra (b), and Central Kalimantan (c) by PCR-RAPD using OPA-11 primer (Description: number (1-10) = samples, $M=$ marker)
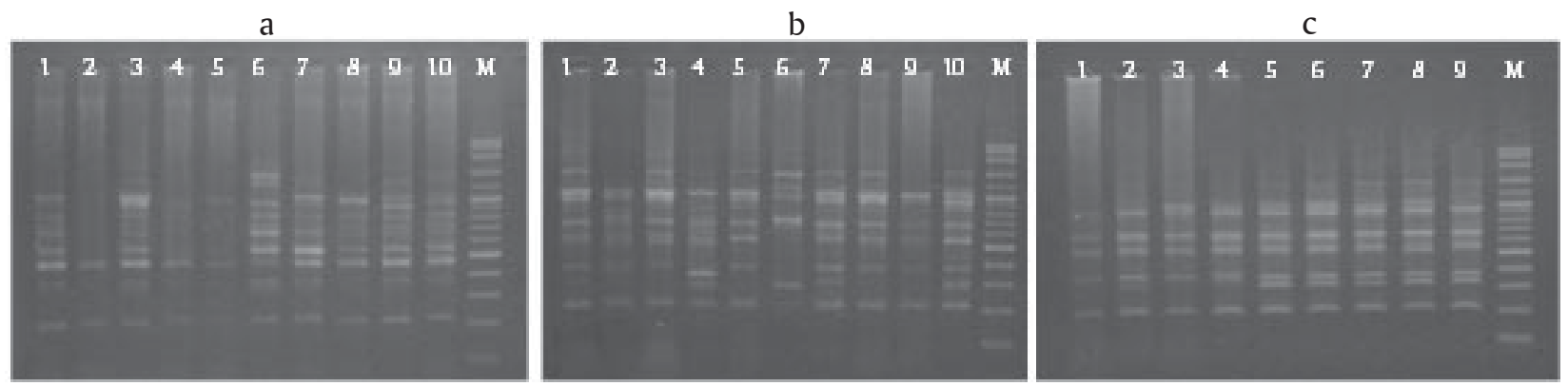

Gambar 4. Hasil amplifikasi DNA ikan gabus Jawa Barat (a), Sumatera Selatan (b), dan Kalimantan Tengah (c) dengan PCR-RAPD menggunakan primer OPA-15 (Keterangan: nomor (1-10) = sampel ikan, $\mathrm{M}=$ marker)

Figure 4. DNA amplification results of snake head from West Java (a), South Sumatra (b), and Central Kalimantan (c) by PCR-RAPD using OPA-15 primer (Description: number (1-10) = samples, $M=$ marker) 
Tabel 2. Persentase polimorfisme dan heterozigositas ikan gabus populasi Jawa Barat, Sumatera Selatan, dan Kalimantan Tengah

Table 2. The percentage of polymorphism and heterozygosity of snakehead from West Java, South Sumatra, and Central Kalimantan

\begin{tabular}{cccc}
\hline $\begin{array}{c}\text { Populasi } \\
\text { Populations }\end{array}$ & $\begin{array}{c}\text { Jawa Barat } \\
\text { West Java }\end{array}$ & $\begin{array}{c}\text { Sumatera Selatan } \\
\text { South Sumatra }\end{array}$ & $\begin{array}{c}\text { Kalimantan Tengah } \\
\text { Central Kalimantan }\end{array}$ \\
\hline Polimorfisme (Polymorphism) (\%) & 30 & 74 & 40 \\
Heterozigositas (Heterozygosity) & 0.121 & 0.2937 & 0.1573 \\
\hline
\end{tabular}

Hasil yang diperoleh pada penelitian ini berbeda dengan yang dilaporkan oleh Gustiano et al. (2013) pada tiga populasi ikan gabus Jawa (Parung), Sumatera (Jambi), dan Kalimantan (Banjar), di mana pada penelitian tersebut nilai polimorfisme dan heterozigositas tertinggi ada pada populasi ikan gabus dari Jawa, yaitu sebesar 83,33\% dan 0,3655 dari 10 ekor sampel setiap populasi dengan tujuh primer yang diuji (OPA-02, OPA-03, OPA-04, OPA-07, OPA-11, OPA20, dan OPC-05). Hasil yang berbeda ini diduga karena lokasi pengambilan sampel ikan dan primer RAPD yang berbeda. Sampel ikan gabus pada penelitian ini diperoleh dari Jawa Barat (Parung), Sumatera (Palembang), dan Kalimantan (Kuala Kapuas). Primer RAPD yang digunakan dalam penelitian Gustiano et al. (2013) adalah OPA-02 sampai OPA-04 dan OPA-07. Mardiana (2007) mengatakan bahwa perbedaan polimorfisme pita DNA yang dihasilkan juga tergantung pada situs penempelan primer dan dapat digunakan untuk memberikan gambaran mengenai tingkat keragaman genetik suatu populasi. Polimorfisme dan heterozigositas menunjukkan potensi kemampuan adaptasi terhadap lingkungannya, karena semakin tinggi heterozigositas maka semakin banyak pula gen yang terlibat dalam menyumbangkan tingkat kebugaran suatu populasi. Polimorfisme adalah ukuran keragaman genetik yang didasarkan pada besarnya proporsi lokus polimorfis terhadap total lokus yang teridentifikasi. Heterozigositas adalah ukuran keragaman genetik berdasarkan jumlah individu heterozigot dari seluruh individu dalam contoh (Soewardi, 2007). Populasi ikan gabus Kalimantan Tengah dan gabus Sumatera Selatan memiliki jarak genetik paling rendah yaitu sebesar 0,4434. Jarak genetik tertinggi pada penelitian ini yaitu antara populasi ikan gabus Jawa Barat dan ikan gabus Sumatera Selatan yaitu sebesar 0,4656. Populasi ikan gabus Jawa Barat dan gabus Kalimantan Tengah memiliki nilai jarak genetik sebesar 0,4645. Jarak genetik masing masing populasi ikan gabus berdasarkan keragaman RAPD menggunakan primer OPA-10, OPA-11, dan OPA-15 ditampilkan pada Tabel 3.

Hasil yang diperoleh pada Tabel 3 menunjukkan nilai yang berbeda dengan Gustiano et al. (2013) yang membandingkan tiga populasi ikan gabus Jawa (Parung), Sumatera (Jambi), dan Kalimantan (Banjar). Jarak genetik pada populasi yang dibandingkan tersebut berkisar antara 0,1170-0,1908. Umumnya semakin rendah jarak genetik di antara populasi yang diamati, maka antara populasi tersebut akan memiliki banyak kemiripan. Jarak genetik yang dekat antar populasi ini menunjukkan adanya aliran genetik antar populasi tersebut, serta adanya interaksi genetik dari reproduksi. Pada penelitian ini jarak genetiknya berkisar antara 0,4434-0,4656; yang berarti antar populasi memiliki lebih sedikit kemiripan dibandingkan dengan penelitian pada ikan gabus yang dilakukan oleh Gustiano et al. (2013).

Tabel 3. Jarak genetik dari ikan gabus populasi Jawa Barat, Sumatera Selatan, dan Kalimantan Tengah berdasarkan marka genetik RAPD

Table 3. Genetic distance of snakehead from West Java, South Sumatra, and Central Kalimantan based on genetic marker RAPD

\begin{tabular}{|c|c|c|c|}
\hline $\begin{array}{l}\text { Populasi } \\
\text { Populations }\end{array}$ & $\begin{array}{l}\text { Jawa Barat } \\
\text { West Java }\end{array}$ & $\begin{array}{l}\text { Sumatera Selatan } \\
\text { South Sumatra }\end{array}$ & $\begin{array}{c}\text { Kalimantan Tengah } \\
\text { Central Kalimantan }\end{array}$ \\
\hline Jawa Barat (West Java) & 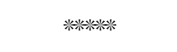 & & \\
\hline Sumatera Selatan (South Sumatra) & 0.4656 & 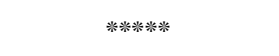 & \\
\hline Kalimantan Tengah (Central Kalimantan) & 0.4645 & 0.4434 & 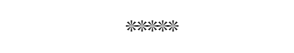 \\
\hline
\end{tabular}

Keterangan (Description): * tidak ada jarak genetik (* no genetic distance) 
Uji perbandingan berpasangan FST (Tabel 4) menunjukkan tidak terdapat perbedaan keragaman genetik yang nyata antara ketiga populasi ikan gabus dari Jawa Barat, Sumatera Selatan, dan Kalimantan Tengah $(\mathrm{P}>0,05)$.

Ikan gabus populasi Kalimantan Tengah memiliki kekerabatan yang dekat dengan ikan gabus dari populasi Sumatera Selatan. Hasil penelitian Gustiano et al. (2013) menunjukkan bahwa populasi ikan gabus dari Kalimantan Selatan (Banjar) dan Sumatera (Jambi) memiliki jarak genetik yang paling rendah. Hal tersebut menunjukkan bahwa ikan gabus dari Pulau Kalimantan mempunyai kekerabatan lebih dekat dengan ikan gabus dari Pulau Sumatera dibandingkan dengan ikan gabus dari Pulau Jawa. Hubungan kekerabatan tiga populasi ikan gabus pada penelitian ini digambarkan dalam bentuk dendrogram interpopulasi (Gambar 5). Dendrogram merupakan hasil gabungan analisis dari tiga primer yang mengelompokkan populasi berdasarkan tingkat kemiripan genetik. Pada Gambar 5 terlihat bahwa hubungan kekerabatan genetik populasi gabus Sumatera Selatan dengan gabus Kalimantan Tengah membentuk satu cluster, sedangkan populasi gabus Jawa Barat terpisah dari cluster pertama. Kekerabatan ikan gabus Kalimantan Tengah lebih dekat atau lebih mirip dengan ikan gabus Sumatera Selatan dibandingkan dengan ikan gabus Jawa Barat.

\section{Keragaman Truss Morfometrik}

Berdasarkan kemiripan fenotipe morfometrik tiga populasi ikan gabus, terlihat ada hubungan yang dekat antara ikan gabus Sumatera Selatan dengan gabus Kalimantan Tengah. Gabus Jawa Barat tidak memiliki kemiripan dengan gabus Sumatera Selatan, serta memiliki kemiripan yang sangat kecil dengan gabus Kalimantan Tengah. Tingkat kemiripan karakter truss dari gabus Sumatera Selatan dan gabus Kalimantan Tengah mencapai 25\%, dan tingkat kemiripan gabus Jawa Barat dengan populasi gabus Kalimantan Tengah hanya $12,5 \%$. Berdasarkan karakter truss morfometrik dari tiga populasi ikan gabus, garis D-1 (akhir sirip anal-awal sirip ekor bawah) merupakan penciri dari ketiga populasi tersebut. Hasil analisis SPSS 16 menunjukkan adanya perbedaan yang nyata $(P<0,05)$ antara karakter D-1 dengan karakter yang lainnya (Tabel 5).

Tabel 4. Uji perbandingan berpasangan FST pada ikan gabus populasi Jawa Barat, Sumatera Selatan, dan Kalimantan Tengah

Table 4. Pairwise comparison FST of snakehead from West Java, South Sumatra, and Central Kalimantan

\begin{tabular}{lccc}
\hline \multicolumn{1}{c}{ Populasi (Populations) } & $\begin{array}{c}\text { Jawa Barat } \\
\text { West Java }\end{array}$ & $\begin{array}{c}\text { Sumatera Selatan } \\
\text { South Sumatra }\end{array}$ & $\begin{array}{c}\text { Kalimantan Tengah } \\
\text { Central Kalimantan }\end{array}$ \\
\hline Jawa Barat (West Java) & - & - \\
Sumatera Selatan (South Sumatra) & $0,0000^{*}$ & $0,0000^{*}$ & - \\
Kalimantan Tengah (Central Kalimantan) & $0,0000^{*}$ & \\
\hline
\end{tabular}

Keterangan (Description): * Tidak berbeda nyata $(\mathrm{P}>0,05)\left({ }^{*}\right.$ no significantly different $\left.(\mathrm{P}>0.05)\right)$

\begin{tabular}{|lllllll} 
& & & & & \\
& & & & & & \\
0.500 & 0.400 & 0.300 & 0.200 & 0.100 & 0.000
\end{tabular}

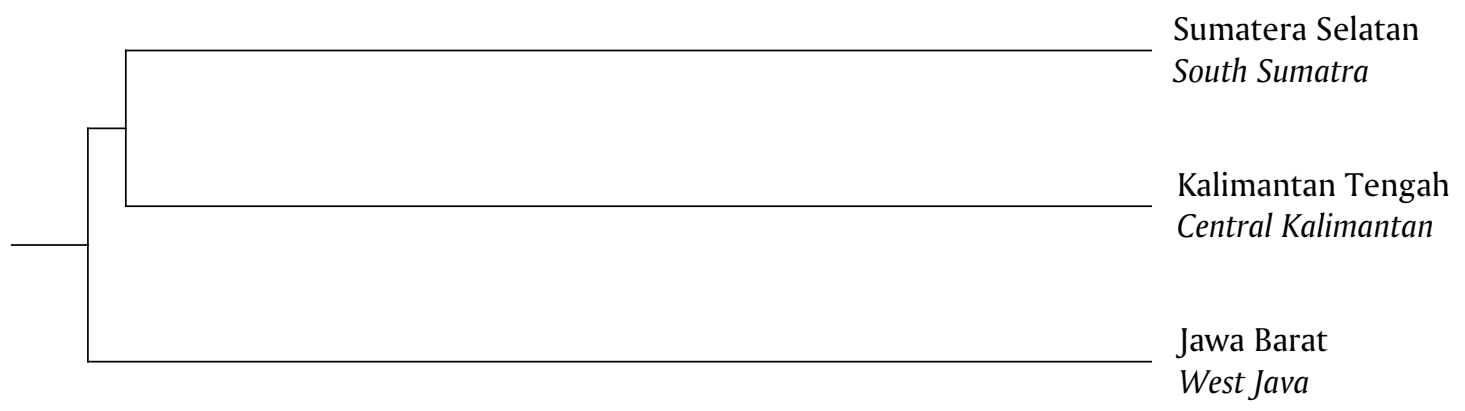

Gambar 5. Dendrogram hubungan kekerabatan dari ikan gabus populasi Jawa Barat, Sumatera Selatan, dan Kalimantan Tengah berdasarkan marka genetik (RAPD)

Figure 5. Genetic relationship dendrogram between snakehead from West Java, South Sumatra, and Central Kalimantan based on genetic marker (RAPD) 
Tabel 5. Nilai rata-rata karakter truss morfometrik ikan gabus (Channa striata) asal Jawa Barat, Sumatera Selatan, dan Kalimantan Tengah

Table 5. Average value of truss morphometric characters of snakehead (Channa striata) from West Java, South Sumatra, and Central Kalimantan

\begin{tabular}{cccc}
\hline \multirow{2}{*}{ Karakter morfometrik } & \multicolumn{3}{c}{ Rataan (Average) } \\
\cline { 2 - 4 } Morphometric characters & Jawa Barat & Sumatera Selatan & Kalimantan Tengah \\
& West Java & South Sumatra & Central Kalimantan \\
\hline A1 & $0.159 \pm 0.016$ & $0.150 \pm 0.010$ & $0.168 \pm 0.016$ \\
A2 & $0.177 \pm 0.014$ & $0.185 \pm 0.11$ & $0.192 \pm 0.014$ \\
A3 & $0.216 \pm 0.026$ & $0.206 \pm 0.014$ & $0.212 \pm 0.018$ \\
A4 & $0.179 \pm 0.016$ & $0.191 \pm 0.012$ & $0.207 \pm 0.010$ \\
A5 & $0.330 \pm 0.011$ & $0.326 \pm 0.014$ & $0.352 \pm 0.008$ \\
A6 & $0.137 \pm 0.016$ & $0.146 \pm 0.009$ & $0.148 \pm 0.011$ \\
B1 & $0.224 \pm 0.013$ & $0.231 \pm 0.014$ & $0.221 \pm 0.008$ \\
B3 & $0.123 \pm 0.022$ & $0.126 \pm 0016$ & $0.138 \pm 0.017$ \\
B4 & $0.262 \pm 0.013$ & $0.275 \pm 0.014$ & $0.279 \pm 0.010$ \\
B5 & $0.362 \pm 0.021$ & $0.377 \pm 0.012$ & $0.384 \pm 0.015$ \\
B6 & $0.150 \pm 0.013$ & $0.162 \pm 0.011$ & $0.176 \pm 0.009$ \\
C1 & $0.382 \pm 0.013$ & $0.381 \pm 0.014$ & $0.380 \pm 0.017$ \\
C3 & $0.612 \pm 0.015$ & $0.625 \pm 0.016$ & $0.607 \pm 0.018$ \\
C4 & $0.428 \pm 0.017$ & $0.101 \pm 0.004$ & $0.010 \pm 0.008$ \\
C5 & $0.1 \pm 0.007$ & $0.607 \pm 0.014$ & $0.598 \pm 0.021$ \\
C6 & $0.601 \pm 0.014$ & $0.429 \pm 0.015$ & $0.429 \pm 0.025$ \\
D1 & $0.428 \pm 0.017$ & $0.089 \pm 0.008$ & $0.086 \pm 0.015$ \\
D3 & $0.084 \pm 0.005$ & $0.055 \pm 0.009$ & $0.057 \pm 0.013$ \\
D4 & $0.097 \pm 0.005$ & $0.100 \pm 0.004$ & $0.099 \pm 0.012$ \\
D5 & $0.112+0.009$ & $0.115 \pm 0.008$ & $0.108 \pm 0.008$ \\
D6 & $0.131 \pm 0.007$ & $0.129 \pm 0.008$ & $0.135 \pm 0.015$ \\
\hline
\end{tabular}

Hasil analisis keragaman truss morfometrik (Tabel 4) menunjukkan bahwa populasi ikan gabus dari Sumatera Selatan memiliki keragaman yang lebih tinggi dibandingkan populasi ikan gabus Kalimantan Tengah atau ikan gabus dari Jawa Barat. Menurut Soewardi (2007), sebagian besar variasi fenotipe antar populasi cenderung disebabkan oleh faktor lingkungan dan sangat sedikit dipengaruhi faktor genetik dan pengaruh perbedaan genetik tersebut pada umumnya terjadi akibat proses seleksi dan adaptasi terhadap kondisi lokal. Mulyasari (2009) mengatakan bahwa ekspresi fenotipe truss morfometrik sangat dipengaruhi oleh lingkungan dan selebihnya merupakan kontribusi yang berasal dari penjumlahan keragaman genetik, serta interaksi antara variasi lingkungan dan genetik. Nilai koefisien variasi suatu karakter mengindikasikan tingkat variabilitas karakter yang bersangkutan pada suatu populasi.

Keragaman populasi ikan gabus Sumatera Selatan baik secara truss morfometrik maupun genotipe memiliki keragaman yang lebih tinggi dibandingkan dengan populasi ikan gabus Kalimantan Tengah atau ikan gabus dari Jawa Barat. Keragaman genetik yang lebih tinggi menunjukkan kemampuan beradaptasi lebih baik dengan perubahan lingkungan yang fluktuatif sehingga bisa bertahan hidup. Spesies yang berada di alam memiliki variasi genetik yang lebih besar dan terbentuk selama proses adaptasi terhadap kondisi alam yang fluktuatif (Tave, 1986). Menurut Mulyasari (2009), beda nyata antar populasi mengindikasikan adanya perbedaan keragaman genetik antar populasi tersebut, sedangkan populasi yang tidak berbeda nyata menunjukkan banyaknya kesamaan genetik antar populasi. Lebih lanjut Setijaningsih et al. (2007) menyatakan bahwa tinggi rendahnya indeks kesamaan sangat dipengaruhi oleh sumber genetik. Analisis terhadap kekerabatan memperlihatkan bahwa jarak genetik populasi ikan gabus Kalimantan Tengah dan Sumatera Selatan lebih dekat dibandingkan dengan populasi dari Jawa Barat. Secara umum semakin rendah jarak genetik di antara populasi-populasi yang diamati, maka semakin banyak kemiripan antar populasi tersebut. Sehingga dapat dikatakan bahwa populasi gabus Kalimantan Tengah memiliki banyak kemiripan 
Tabel 6. Koefisien keragaman (CV) dari 16 karakter truss morfometrik dari ikan gabus (Channa striata) asal Jawa Barat, Sumatera Selatan, dan Kalimantan Tengah

Table 6. Coefficient of variation (CV) from 16 truss morphometric characters of snakehead (Channa striata) from West Java, South Sumatra, and Central Kalimantan

\begin{tabular}{|c|c|c|c|c|}
\hline \multirow{2}{*}{$\begin{array}{l}\text { Karakter morfometrik } \\
\text { Morphometric characters }\end{array}$} & \multicolumn{3}{|c|}{ Koefisien keragaman (Coefficient of variation) (\%) } & \multirow{2}{*}{$\begin{array}{l}\text { Signifikansi } \\
\text { Significance }\end{array}$} \\
\hline & $\begin{array}{c}\text { Jawa Barat } \\
\text { West Java }\end{array}$ & $\begin{array}{c}\text { Sumatera Selatan } \\
\text { South Sumatra }\end{array}$ & $\begin{array}{c}\text { Kalimantan Tengah } \\
\text { Central Kalimantan }\end{array}$ & \\
\hline A1 & 9,883 & 6,788 & 9,508 & .138 \\
\hline $\mathrm{A} 2$ & 7,878 & 5,875 & 7,042 & .489 \\
\hline A3 & 12,225 & 6,651 & 8,645 & .455 \\
\hline A4 & 8,705 & 6,029 & 5,032 & .137 \\
\hline A5 & 3,349 & 4,256 & 2,383 & .304 \\
\hline A6 & 11,806 & 5,898 & 7,755 & .217 \\
\hline B1 & 5,852 & 6,017 & 3,673 & .071 \\
\hline B3 & 17,715 & 12,459 & 12,639 & .132 \\
\hline B4 & 5,012 & 5,152 & 3,639 & .059 \\
\hline B5 & 5,908 & 3,192 & 3,963 & .071 \\
\hline B6 & 8,536 & 6,867 & 5,074 & .108 \\
\hline $\mathrm{C} 1$ & 3,314 & 3.7 & 4.56 & .060 \\
\hline $\mathrm{C} 3$ & 2,482 & 2,579 & 2,974 & .046 \\
\hline $\mathrm{C} 4$ & 7,051 & 4,037 & 7,494 & .148 \\
\hline C5 & 2,377 & 2,368 & 3,539 & .070 \\
\hline C6 & 3.89 & 3,592 & 5,794 & .053 \\
\hline D1 & 6,177 & 9,023 & 16,874 & $.036^{*}$ \\
\hline D3 & 14,027 & 15,971 & 22,104 & .790 \\
\hline D4 & 5,318 & 4,026 & 11,977 & .051 \\
\hline D5 & 7,773 & 6,535 & 7,603 & .148 \\
\hline D6 & 5,672 & 6,253 & 9,847 & .324 \\
\hline
\end{tabular}

Keterangan (Description): * Berbeda nyata $(\mathrm{P}<0,05)($ * Significantly different $(P<0.05))$

genetik dengan populasi gabus Sumatera Selatan.Jarak genetik yang dekat antar populasi ini menunjukkan adanya aliran genetik (gene flow) antar populasi tersebut, serta adanya interaksi genetik dari reproduksi.

\section{KESIMPULAN}

Keragaman secara truss morfometrik dan genotipe populasi ikan gabus Sumatera Selatan lebih tinggi dibandingkan keragaman populasi ikan gabus Kalimantan Tengah dan Jawa Barat. Ikan gabus Sumatera Selatan lebih berpotensi sebagai kandidat dalam program pemuliaan. Kekerabatan secara truss morfometrik maupun genotipe menunjukkan ikan gabus Kalimantan Tengah lebih dekat atau lebih mirip dengan ikan gabus Sumatera Selatan dibandingkan dengan ikan gabus Jawa Barat.

\section{DAFTAR ACUAN}

Dunham, R.A. (2004). Aquaculture and fisheries biotechnology: genetic approach. CABI Publishing. Cambridge MA, 367 pp.

Gustiano, R. (2007). Kajian teknis dan sosioekonomis pengelolaan berkelanjutan sumberdaya genetik ikan. Prosiding Lokakarya Nasional Pengelolaan dan Perlindungan Sumber daya Genetik di Indonesia: Manfaat Ekonomi untuk Mewujudkan Ketahanan Nasional, hlm. 48-53.

Gustiano, R., Oktaviani, T., Soelistyowati, D.T., Kusmini, I.I., Wahyutomo, \& Huwoyon, G.H. (2013). Analisis ragam genotipe RAPD dan fenotipe truss morfometrik pada tiga populasi ikan gabus (Channa striata) Bloch, 1793. Berita Biologi, 12(3), 325-333. 
Hassanien, H.A., Mohumad, E., Ali, O., \& Hania, I. (2004). Genetic diversity of nile tilapia populations revealed by randomly amplified polymorphic DNA (RAPD). Aquaculture Research, 35, 587-593.

Kordi, M. (2010). Buku pintar pemeliharaan 14 ikan air tawar ekonomis di keramba jaring apung. Lily Publisher. Yogyakarta, 324 hlm.

Mardiana, T.Y. (2007). Karakteristik klon ikan Sumatera (Puntius tetrazona Bleeker) hasil ginogenesis. Tesis. Institut Pertanian Bogor. Bogor, 48 hlm.

Mohd Shafri, M.A., \& Abdul Manan, M.J. (2012). Therapeutic potential of the haruan (Channa striatus): from food to medicinal uses. Malaysian Journal of Nutrition, 18(1),125-136.

Mulyasari. (2009). Karakteristik fenotipe morfometrik dan keragaman genotipe RAPD (Random Amplified Polymorphic DNA) ikan nilem (Osteochilus hasselti) di Jawa Barat. Tesis. Institut Pertanian Bogor. Bogor.

Nei, M. (1978). Estimation of average heterozygosity and genetic distance from a small number of individual genetics, 89, 583-590.

Nugroho, E., Takagi M., \& Taniguchi N. (1997). Practical manual on detection of DNA polymorphism in fish population study. Kochi University. Bulletin of Marine Sciences and Fisheries, p. 109-129.
Rogers, J.S. (1972). Measures of similarity and genetic distance. Studies in Genetics VII. University of Texas Publication, 7213, 145-153.

Setijaningsih, L., Arifin, O.Z., \& Gustiano, R. (2007). Karakterisasi tiga strain ikan gurame (Osphronemus gourami Lac.) berdasarkan metode truss morfometrik. Jurnal Iktiologi Indonesia, 7(1), 2330.

Singh, R.K., \& Chaudary, B.D. (1977). Biometrical methods in quantitative genetics analysis. Kalyani Publishers. New Delhi, 304 pp.

Strauss, R.E., \& Fuiman, L.A. (1985). Quantitative comparisons of body form and allometry in larval and adult Pacific sculpin (Teleostei: Cottidae). Canadian Journal of Zoology, 63, 1582-1589.

Soewardi, K. (2007). Pengelolaan keragaman genetik sumberdaya perikanan dan kelautan. Institut Pertanian Bogor. Bogor, 153 pp.

Tave, D. (1986). Genetic for fish hatchery managers. The AVI Pub. Comp. Inc., Westport. Connecticut, 299 pp.

Wright, S. (1978). Evolution and the genetics of populations, vol. 4. Variability within and among natural populations, University of Chicago, 590 pp. 
